A special search was made for sulphur and phosphorus, giving the figures :-

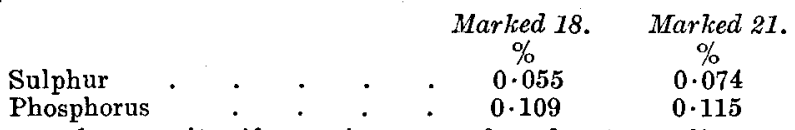

Both samples are titaniferous iron-ore of moderate quality.

25 Cadogan place, London, S.W.1.

Ernest Gibson. May 5, 1918.

OBITUARY.

\title{
PROFESSOR GEORGE ALEXANDER LOUIS LEBOUR, M.A., D.Sc., F.G.S., Vice-Principal of the Armsthong College, Newcastle-Upon-Tyna.
}

BORN 1847.

Died February 7, 1918.

QY the death of Professor Lebour in his 71st year, on February 7, $B 1918$, the scientific world loses a prominent and interesting figure. Born in 1847 and educated at the Royal School of Mines, he served from 1867 to 1873 on the Geological Survey of England and Wales. He was lecturer in geological surveying at the University of Durham College of Science (later, Armstrong College) in Newcastle from 1873 to 1879 , and succeeded Dr. David Page as Professor of Geology in the University. This position he occupied until his death, so that for forty-five rears he was connected with the College, and for thirty-nine years occupied the chair of Geology. In 1904 he was awarded the Murchison Medal by the Council of the Geological Society, and in the same year was elected Vice-Principal of Armstrong College.

The transference of heat through the crust of the earth occupied Lebour's attention early and led to measurements of underground temperature in northern coal-pits, and also in conjunction with Herschel, to the determination of the thermal conductivities of a great number of rocks. This important work, issued in a series of British Association reports from 1873 to 1881 , is well known, and many of the data obtained are accepted as stundard.

Lebour's name will always be associated with the geology of Northumberland and Durham. Besides his official maps, he brought out in 1877 an excellent geological map of the county of Northumberland, which is the embodiment of much strenuous, clear-sighted labour. He was joint author with William Topley of a widely quoted paper on the Great Whin Sill, which may be said to have definitely established its intrusive character. The stratigraphical relations of the Carboniferous rocks form the subject of many papers, in which the divisions of the system and the description and correlation of the important limestones, etc., are set forth with admirable lucidity. The economic aspects of the subject find expression in papers on the Redesdale Ironstones and the coals of the Bernician series, especially those associated with the Little Limestone. The future importance of these coals, which occur in 
rocks below the Coal-measures proper, is strongly insisted upon, and the lapse of forty years has but added strength to the views then brought forward. Of many papers relating to the Geology of Durham may be noted those dealing with the classification of the Salt-measures, the breccia-filled fissures in the Magnesian Limestone (aptly termed by him breccia-gastes), and the Marl Slate and Yellow Sands.

As many as nineteen papers are recorded under Lebour's name in the Geological Magazine Index from 1869 to 1887 , but he has contributed over one hundred papers on geological subjects to various journals. One of these of special interest, published as long ago as in July, 1876, on "The Carrara Marbles", gives a most instructive history of the geological vicissitudes undergone $b y^{\prime}$ these highly metamorphosed Limestone. Rocks from their reference to Eruptive and Cretaceous Oolitic, Jurassic, Iiassic, Rhætic, and finally being assigned to the Lower Carboniferous age by Coquand on the evidence of fossils. The similar saccharoidal limestones of St. Béat in the Pyrenees have also been, on the evidence of fossils, proved to be equivalent to the statuary marbles of Carrara and of like Carboniferous Limestone age. (GeoL. MAG., 1876, pp. 289-92 and p. 382.)

Lebour wrote "The Geology of Durham" in the Fictoria History and the Handbook to the Geology and Natural History of Northumberland and Durham, of which three editions have appeared (1878-89). It is a very effective monument to his life-work in the two counties, and has the remarkable merit of increasing in value the more it is used.

This brief narrative of work accomplished gives, however, no true estimate of Lebour's scientific activity and influence. $\mathrm{He}$ was a many-sided man, of wonderful fluency, both in the written and spoken word, and a born teacher. His papers are models of clearness and skilful arrangement of material; they are written in flawless English, and they often display that sense of humour which was one of his notable characteristics. These same qualities were, if possible, accentuated in his lectures. He inspired a great band of workers, who have carried his methods and enthusiasm to the four quarters of the globe, and he was ever ready to help, by his sage advice, those whose steps he had directed towards scientific paths.-From Nature, February 21, 1918.

He leaves a widow and two daughters with a wide circle of personal and scientific friends to cherish his memory.

\section{ROBERT MACKENZIE JOHNSTON.}

Mr. R. M. Johnston, the well-known Registrar-General and Government Statistician of Tasmania, was born at Inverness, educated at the Andersonian University of Glasgow, and went to Australia at the age of 26 . He was the author of many works on Tasmanian natural history, notably the Systematic Account of the Geology of T'asmania, 1888. He received the I.S.O. in 1903, and died at Hobart on April 20, 1918.-Morning Post. 